\title{
LEVEL OF THE CURRENT LIQUIDITY RATIO VERSUS FINANCIAL EFFICIENCY OF DAIRY COOPERATIVES
}

\author{
MARZENA GANC
}

\begin{abstract}
The study shows the efficiency of the dairy cooperative depending on the level of their current financial liquidity. Cooperatives were grouped according to the current liquidity ratio using quartiles methods and significance e test of the differences between the groups was conducted on the groups. Adopted to verify the hypothesis that dairy cooperatives with liquidity above the recommended standards of literature show highest efficiency adopted for verification. The most advantageous financial conditions were characterized by dairy cooperatives with liquidity above and within the limits recommended in the literature. This may be due to the fact that having adequate levels of liquidity may be in the form of cooperative farming more important than maximizing financial performance.
\end{abstract}

Keywords: dairy cooperatives, current financial liquidity, efficiency of dairy cooperatives.

Kody JEL: P12, Q13, Q14.

\section{Introduction}

Dairy cooperatives play an important economic role not only in Poland, but also in North America and Western Europe. According to Chaddad and Cook, the managers of these entities succeed thanks to the ability to generate and maintain equity as well as flexibility of payments to members of the cooperative (Chaddad and Cook, 2010). The integration of the cooperative nature of the objective and profitability has a fundamental impact on the financial liquidity of this group of legal entities (Akridge and Hertel, 1992).

Dr Marzena Ganc, Szkoła Główna Gospodarstwa Wiejskiego, Wydział Nauk Ekonomicznych, Katedra Finansów, ul. Nowoursynowska 166, 02-787 Warszawa (marzena_chmielewska@sggw.pl). 
One of the basic conditions for the continuation and development of an enterprise in a competitive market is to ensure financial security (Manfredo and Richards, 2007). Without it, an enterprise is not a reliable entity that fulfils its objectives against stakeholders, i.e. owners, management entities, creditors, employees, customers, suppliers, strategic partners and the local community. This is particularly important in the assessment of cooperative entities whose business objective is not the maximum financial result, but the benefit for farmers, milk suppliers (Wasilewski and Chmielewska, 2006).

The ability of an enterprise to continue operations may translate into company's balanced inflows and expenses in the future (Karbownik, 2012). According to the company's financial safety assessment, it is assumed - in accordance with the accounting principle - that the entity does not intend to discontinue its business activity or significantly limit its scope (Bednarski et al., 1996). In turn, the development of the enterprise is a more complex issue, resulting from the variability and diversity and the existing state of affairs. It is a long-lasting process of quantitative and qualitative changes leading to the diversification and enrichment of the components of the company's resources and the relations between them (Sierpińska and Jachna, 2002). The undertaking and development of business requires the availability of appropriate resources, including financial resources (Michalski, 2001). Actually owned or potentially available financial resources of an enterprise should protect a given economic entity from external and internal threats, ensuring continuation of the company's business and financial conditions for its further development (Wędzki, 2003).

The financial effectiveness of dairy cooperatives is influenced by the nature of a cooperative perceived as a complex picture of the following aspects: the unique structure, organisation, management, capital financing and operation of cooperatives; market results of cooperatives; and cooperative relations with other market participants (Ling, 2012). The assessment of financial efficiency is, therefore, a complex problem in the field of financial analysis due to the specifics of the cooperative's activities. Specific measures can be distinguished, taking into account the specificity of the relationship between the farmer-supplier and the cooperative-employer:

- ACAV (Abnormal Cooperative Additional Value) - a measure of financial effectiveness assessment, postulated by Pietrzak (2006), which is the sum of economic profits and an extraordinary price premium;

- adjusted profitability ratios, proposed by Dworniak (2010), apart from the classical net profit, taking also into account the payments to the participation fund.

Literature review indicated that there are not many dedicated measures of effectiveness of the cooperative, and the existing measures (with the exception of Dworniak's adjusted profit) are measures of economic efficiency. Establishing efficiency within the so-called the ratio analysis is based on the calculation of the relationship of effects to cost, expenditure or capital employed. In addition, the effect is often understood as the absolute difference between the results and related charges (costs, inputs, or expenses) (Soliwoda, 2012a; Łukasik, 2009). What is more, efficiency is most often assessed using the index-based and non-parametric 
methods. According to Pietrzak (2006), meaningful cooperative efficiency ratios should be positively correlated with positive results achieved in areas such as: market position, economic processes, IT potential or supplier base (development of the raw material base, strengthening ties with members of the cooperative).

Taking into account the research objective, financial efficiency will be considered in the study as maintenance of financial analysis indicators within the range which is standard for a given sector.

The level of the current liquidity ratio depends on the specifics of the entity's operations, decisions made by the management of the enterprise (Soliwoda, 2012b), as well as on the adopted accounting policy for inventory valuation (Chadwick, 1984). In the opinion of Franc-Dąbrowska, one can only talk about quasi-optimum liquidity ratios, in particular in the case of agribusiness enterprises (FrancDąbrowska 2008). This statement is true in particular with reference to cooperative business entities, for which the main purpose of the activity is to maximise the benefits of its members, rather than to bring high financial results. At the same time, Soliwoda showed in the research from 2004-2009 that dairy cooperatives were rationally shaped by current, rapid and immediate financial liquidity, and aimed at accelerating inventory turnover, increasing the self-financing of current assets and reducing the need for working capital (Soliwoda, 2012a).

Not much research in foreign literature is concerned with the financial effectiveness of the cooperative, Soboh, Oude Lansink and van Dijk (2011), however, used logistic regression to analyse differences in financial indicators and results between European dairy cooperatives and investor-owned enterprises. In terms of financial liquidity ratios, cooperatives record higher liquidity than commercial cooperative entities.

According to Domańska's research, managers of dairy cooperatives in 2010-2012 maintained financial liquidity ratios at a level not threatening the risk of losing the ability to pay short-term liabilities on time. In the examined group of dairy cooperatives, regardless of the scale of their operations and the size of their own fund, the managers showed a rather conservative approach to the risk of losing financial liquidity. In addition, Domańska proves that managers of dairy cooperatives have shaped relations between the value of current assets and short-term liabilities depending on the volume of accumulated own funds in a different way. Together with the increase in own funds, managers of dairy cooperatives increased the level of current and quick financial liquidity (Domańska, 2015).

Chmielewska attempted to find such a range of current liquidity ratio for dairy cooperatives, at which they obtain the highest level of financial efficiency and management effectiveness (Chmielewska, 2006). This study is a continuation of research into the financial liquidity of dairy cooperatives.

\section{Research objectives and methods}

The study aims to determine the level of profitability, efficiency of management and the level of indebtedness of dairy cooperatives depending on their current financial liquidity. This indicator was chosen due to the purpose of a cooperative, 
consisting in e.g. increasing the benefits of co-owners (farmers-suppliers) who want to receive payments for the delivered milk raw material as quickly as possible. These payments are mainly current liabilities of cooperatives, therefore, the ability to deliver them is a priority for managing cooperatives. The source empirical data comes from individual annual financial statements published in Monitor Spółdzielczy B, pursuant to the Act on Accounting. The study reseached 88 dairy cooperatives which continued to operate in the analysed period. The test sample can be treated as quasi-representative due to the marginal share in milk purchase of other (not included in the study) dairy cooperatives. The research covered the period between 2011 and 2014. Cooperatives were grouped according to the current liquidity index using the quartile method ${ }^{1}$ and a test was made for the significance of differences between groups in order to determine the validity of the adopted groupings ${ }^{2}$. The test confirmed the differences between the separate groups of cooperatives. The first group of cooperatives covered $25 \%$ of their population (lower quartile) with the highest current liquidity, the second with the average (50\% of the population) and the third group - the lowest (25\% of the population). The author assumed the hypothesis that dairy cooperatives with liquidity above the recommended literature standards (showing excess liquidity) show the highest financial efficiency. The ranges of the current liquidity ratio in individual groups of cooperatives are presented in Table 1.

Table 1

The ranges of the current liquidity ratioa in separate groups of dairy cooperatives

\begin{tabular}{|c|c|c|c|c|}
\hline \multirow{2}{*}{$\begin{array}{c}\text { Groups } \\
\text { of cooperatives }\end{array}$} & \multicolumn{4}{|c|}{ Years } \\
\hline & 2011 & 2012 & 2013 & 2014 \\
\hline $\begin{array}{l}\text { Group I } \\
\text { with the highest } \\
\text { current liquidity }\end{array}$ & $2.0-3.8$ & $2.1-4.8$ & $2.0-4.5$ & $2.0-6.0$ \\
\hline $\begin{array}{l}\text { Group II } \\
\text { with average } \\
\text { current liquidity }\end{array}$ & $1.1-1.9$ & $1.1-2.0$ & $1.1-1.9$ & $1.1-1.9$ \\
\hline $\begin{array}{l}\text { Group III } \\
\text { with the lowest } \\
\text { current liquidity }\end{array}$ & $0.5-1.0$ & $0.5-1.0$ & $0.6-1.0$ & $0.5-1.0$ \\
\hline
\end{tabular}

${ }^{a}$ Calculated as the quotient of current assets and short-term liabilities.

Source: own study.

\footnotetext{
${ }^{1}$ This method consists in dividing the collective into four equal parts in ascending order for a given criterion. There are only three quartiles, the first of which divides the population into $1 / 4$, in which all units have the highest value for the selected criterion, and the remaining $3 / 4$ of the population includes elements with lower characteristics. The second quartile divides the population into two equal parts. The third quartile separates $3 / 4$ of the population with lower trait values than $1 / 4$ of the population with its highest values. The first group of cooperatives covered $25 \%$ of their population (lower quartile) with the highest value of equity, the second with the average (50\% of the population) and the third group - the lowest ( $25 \%$ of the population).

${ }^{2}$ In the case of respective cooperative groups, it was reasonable to use the Kruskal-Wallis test, because there are more than two groups being compared.
} 
The level of current financial liquidity of dairy cooperatives with the highest ratios increased from 2.0-3.8 in 2011 to 2.0-6.0 in 2014. Overall financial liquidity in the second group of cooperatives (average liquidity) was 1.1-1.9 and was basically the same in each of the years under examination, while in the group of cooperatives with the lowest overall liquidity, the level of the indicator was from 0.5 up to 1.0. It is worth adding that cooperatives with the highest level of current liquidity were also characterised by the highest equity and total assets. It can, therefore, be concluded that these were large dairy cooperatives, not only in terms of the indicator being examined.

\section{Findings}

The profitability of the assets of the analysed cooperatives was at a relatively low level (Figure 1). In 2011-2013, the profitability of total assets decreased as the current financial liquidity decreased. Wasilewski and Chmielewska (2006) obtained similar results. It can, therefore, be concluded that there is a relationship between profitability and financial liquidity in dairy cooperatives. In cooperative forms of management, profit is not the goal of activity but enables development and presence on the market. Managers of dairy cooperatives must balance the goal of maximising benefits for members of the cooperative while maintaining an appropriate level of net financial result. The highest level of profitability of total assets was found in 2013 in cooperatives with overall liquidity in the range of 2.0-4.5, where it amounted to 5.5\%. In 2013, the highest assets profitability in all cooperative groups was also recorded in relation to the remaining years covered by the analysis. In 2012, the lowest positive profitability of assets was reported by cooperatives with the lowest liquidity levels (0.5-1.0).

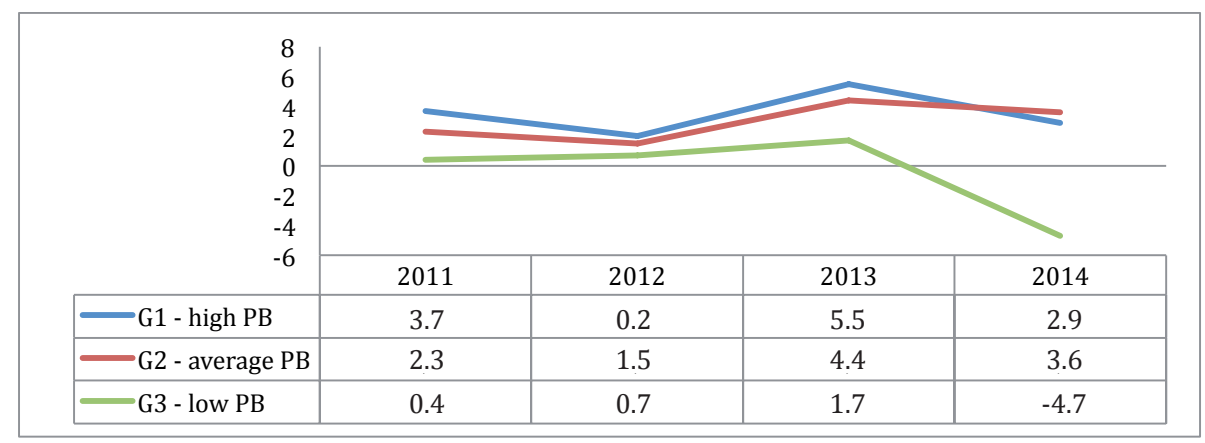

PB - current liquidity

${ }^{\text {a }}$ Calculated as the quotient of net profit to total assets $* 100 \%$.

Fig. 1. Return on assets (ROA) $)^{\mathrm{a}}$ depending on the level of current financial liquidity (\%).

Source: own study. 
Taking into account the specificity of cooperative forms of management, the profitability of assets should be assessed favourably, except for those cooperatives where the lowest current financial liquidity occurred in 2014 (the assets profitability rate was $-4.7 \%$ ). In addition, for that year the highest profitability of total assets was recorded by cooperatives with an overall liquidity level in the range of 1.1-2.0. Such a situation may have been caused by the fact that dairy cooperatives are characterised by relatively low profitability, but maintain adequate (according to literature) level of financial liquidity ratios.

Figure 2 presents the development of the return on equity depending on the level of current financial liquidity. As in the case of ROA, in 2011-2013 a relationship was found between the profitability of own funds and overall liquidity, i.e. with the decrease of the level of financial liquidity, the profitability of equity was also reduced. The figures observed in 2014 were the exception in this respect, where the highest level of profitability was recorded in cooperatives with current financial liquidity in the range of 1.1-1.9 (return on equity ratio of $6.2 \%$ ). According to the author's research carried out in 2004-2006, cooperatives showed the highest return on equity when the overall liquidity ratio ranged from 1.24 to 3.80 .

Summing up, it can be concluded that cooperatives with the highest current financial liquidity (2.0-4.5) achieved relatively the highest return on assets and equity. It is worth noting that according to literature standards in the field of overall liquidity, these cooperatives would be qualified as having excess liquidity (overliquidity). In the cooperative forms of business management, the issue of financial liquidity should be considered taking into account the specificity of their activity. Maintaining high ability to satisfy current liabilities determines good functioning of a cooperative on the market, primarily in the aspect of maintaining the continuity of supply of dairy raw materials.

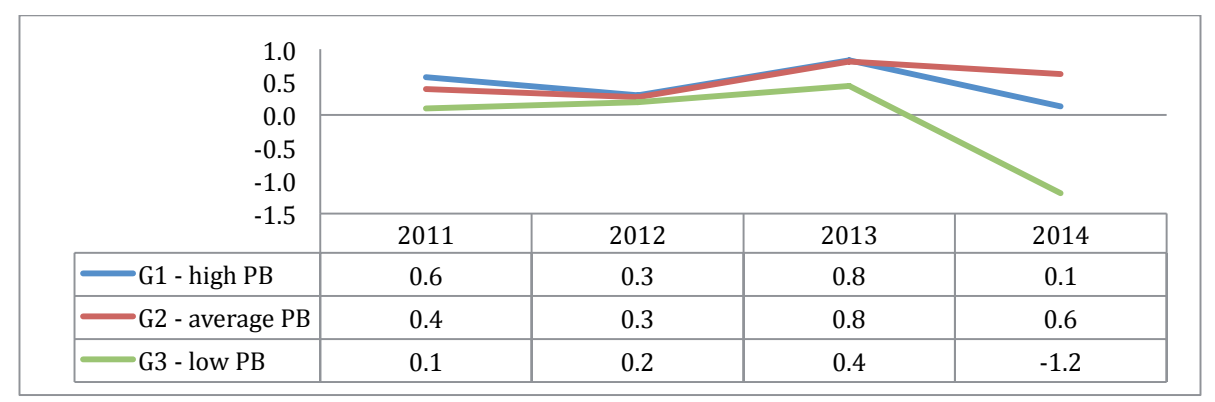

${ }^{\text {a }}$ Calculated as the quotient of net profit and equity $* 100 \%$.

Fig. 2. Return on equity (ROE)a and the liquidity level (\%).

Source: own study. 
The examined dairy cooperatives showed a relatively low effectiveness of using foreign sources of financing. The lowest ratio of financial leverage was recorded in cooperatives with current liquidity in the range of $0.5-1.0$, while the highest in those with a financial liquidity of 1.1-1.9. The lack of a visible relationship between the efficiency of using foreign capital and overall financial liquidity may be caused by the fact that dairy cooperatives make use of short-term sources of financing of activities, such as loans or credits, to a marginal extent.

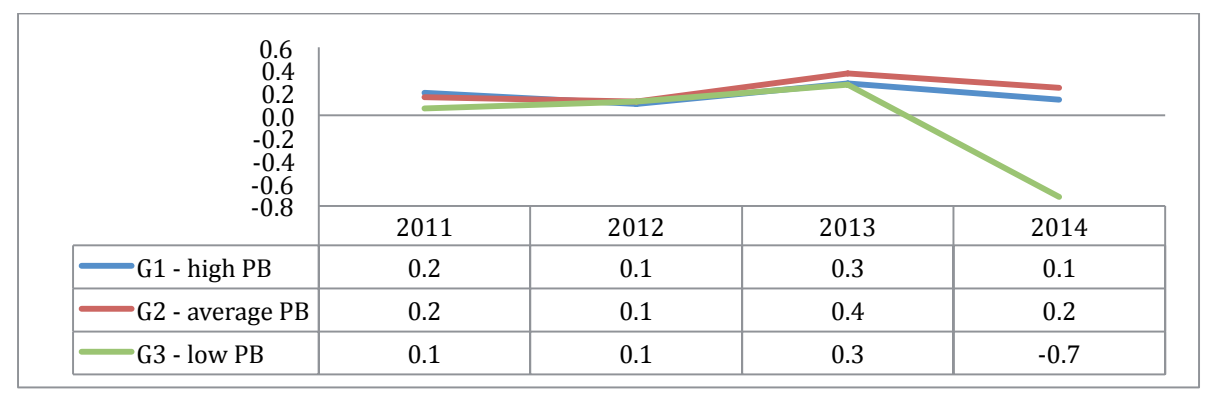

Fig. 3. Financial leverage and current liquidity of dairy cooperatives (\%).

Source: own study.

Figure 4 presents the development of quick liquidity ratio in the studied cooperative groups, which is aimed at determining changes in the dynamic approach, because the relationship between indicators is obvious. In all groups of dairy cooperatives in 2011-2014, the level of quick liquidity ratio was basically stable.

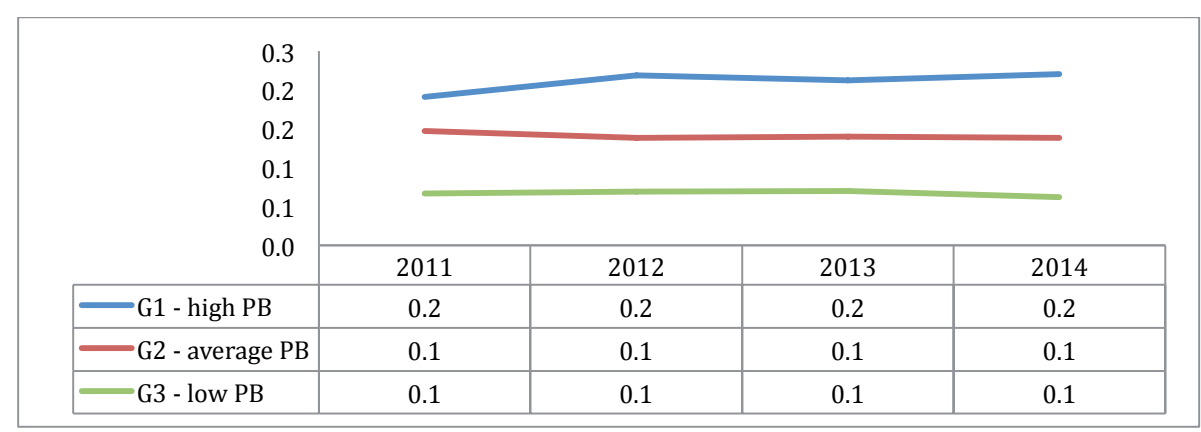

Fig. 4. The level of quick liquidity ratio and overall liquidity of dairy cooperatives.

Source: own study.

Taking into account the recommended levels of this indicator presented in literature, it can be noticed that in the first group there is a phenomenon of significant financial liquidity over the analysed period (quick liquidity ratio at the level of literature standards regarding overall liquidity). A similar situation was observed in the second group, but in this case it slightly exceeded literature standards. 
Cooperatives with the current liquidity of $0.5-1.0$, also in the aspect of quick liquidity, did not reach the recommended values of the indicator. The highest rate of quick financial liquidity was found in 2012 and 2014 in cooperatives with current liquidity at the level of 2.0-4.5.

Figure 5 presents the development of the immediate cash flow ratio of the examined dairy cooperatives.

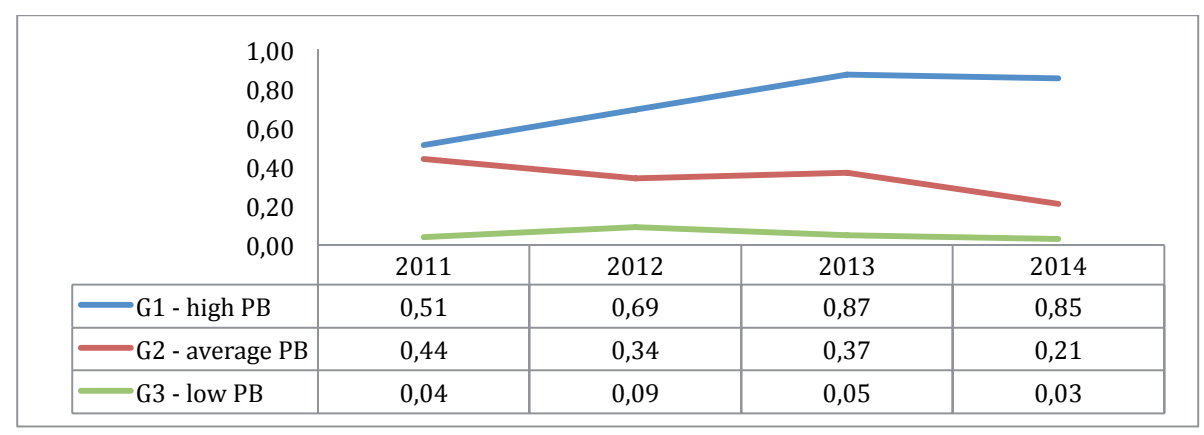

Fig. 5. Cash flow indicator and current liquidity

Source: own study.

Taking into account literature standards at the level of 0.2 , it can be stated that only cooperatives in the first and the second group exceeded the values in this respect, while those in the third group did not maintain adequate levels of cash liquidity. In the case of cooperatives with current liquidity within the range of 2.0-6.0, excess liquidity was also recorded within the aspect of immediate liquidity. The highest level in this respect was found in 2013 in cooperatives from the first group (0.87).

Figures 6,7 and 8 present the development of receivables and liabilities turnover in days. Comparing these ratios in cooperatives with the highest overall liquidity, it can be concluded that the period of satisfying obligations was shorter than the time of inflow of receivables. From the point of view of theory in this respect, this phenomenon may be considered unfavourable, but considering the results of these analyses with the financial liquidity of the cooperatives studied, it should be assessed rather favourably. Managers of the largest cooperatives in terms of the adopted criterion, purposely maintain a high level of financial liquidity to be able to meet current obligations towards their members (farmers-suppliers of raw milk) who have priority in receiving payment for delivered milk. At the same time, these cooperatives are pursuing a more liberal policy regarding deadlines for receivables from recipients. In cooperatives with current liquidity in the range of 2.0-6.0, there was a tendency to shorten the time of satisfying financial obligations from 47 days in 2011 to 41 days in 2014. The shortest turnover of receivables was found in these cooperatives in 2012, when it amounted to 33 days. 


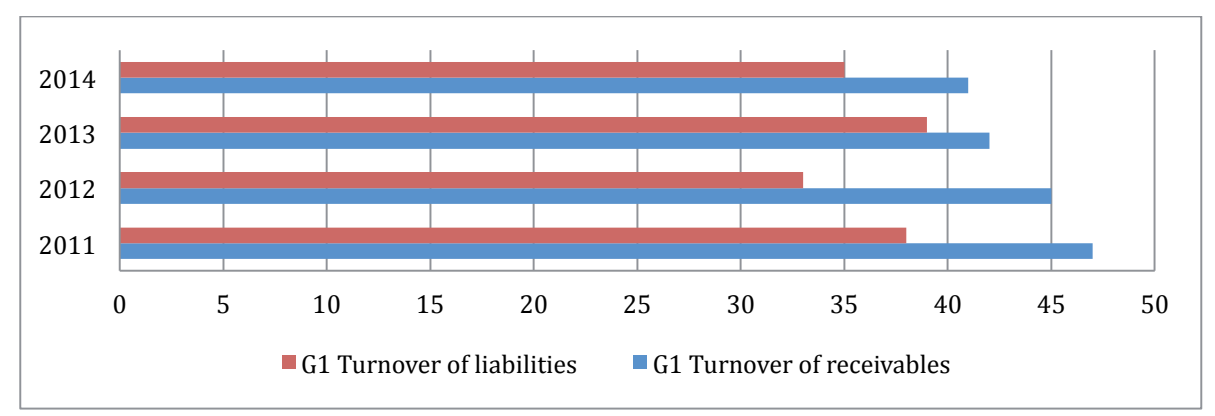

Fig. 6. Comparison of turnover ratios for receivables and short-term liabilities in a group of cooperatives with the highest current liquidity (days).

Source: own study.

In cooperatives in the second and third groups, according to the adopted criterion, the payment period was generally longer than the debt realisation time (Fig. 7 and 8). The exception in this respect was 2014, when cooperatives with current financial liquidity in the range of 1.1-1.9 showed an identical level of turnover in receivables and liabilities (36 days). At the same time, it was the shortest period of implementation of liabilities and receivables.

In cooperatives with an overall financial liquidity ranging from 0.5 to 1.0 , a significantly longer repayment period was observed in relation to the period of delivery of trade receivables. This situation may result from the fact that cooperatives with low financial liquidity pay off current liabilities with cash from paid receivables. Managers of these cooperatives do not need to maintain a high level of financial liquidity. In cooperatives where there was no excess liquidity (group two and three) the difference between the receivables turnover rates and liabilities was about 10 days. In summary, the repayment period of receivables and liabilities of surveyed cooperatives should be evaluated favourably. Cooperative managers adjust the level of cash owned to the specifics of the company's operation.

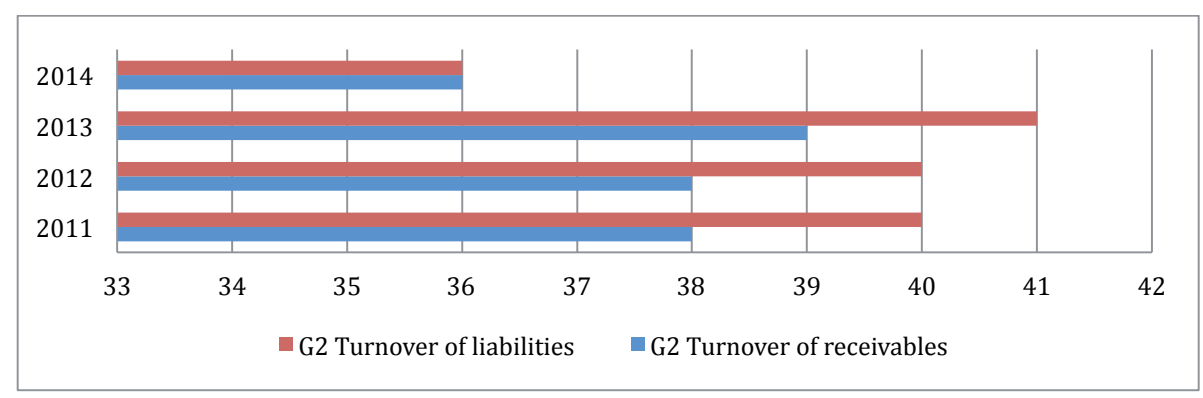

Fig. 7. Comparison of turnover ratios for receivables and short-term liabilities in a group of cooperatives with an average level of current liquidity (days).

Source: own study. 


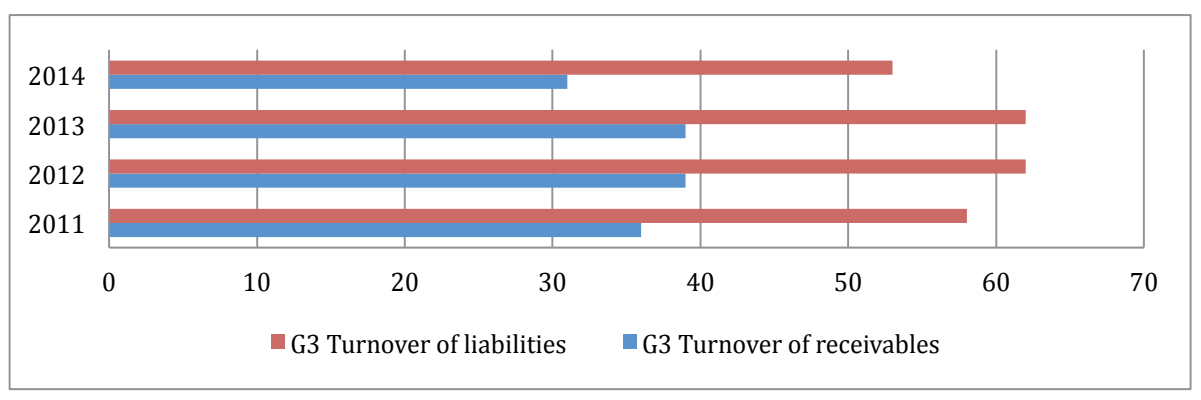

Fig. 8. Comparison of turnover ratios for receivables and short-term liabilities in a group of cooperatives with the lowest level of current liquidity (days).

Source: own study.

The general indebtedness of the surveyed cooperatives is shown in Figure 9. In general, there was a downward trend in this area in all cooperative groups, regardless of the level of current financial liquidity. The lowest level of indebtedness was found in cooperatives with the highest overall liquidity (2.0-6.0 in the analysed period).

It is justified by the fact that cooperatives keep the money available and there is no need to use foreign sources of financing. It should also be borne in mind that cooperative managers have risk aversion and are not inclined to incur short-term bank loans. If they need additional sources to finance their operation, they make significant use of long-term financing.

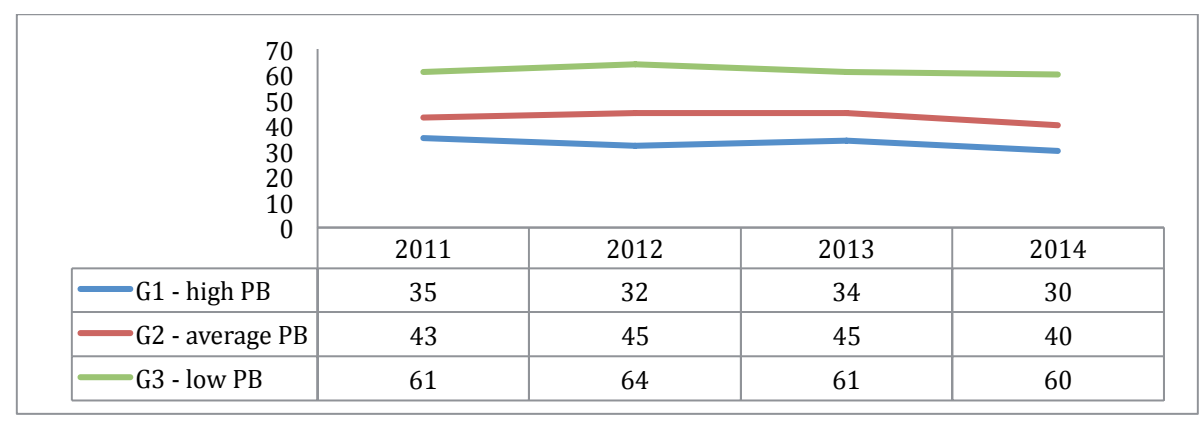

Fig. 9. Level of general debt of a cooperative depending on their liquidity (\%) Source: own study. 


\section{Conclusions}

The study presents the financial condition of dairy cooperatives depending on the level of current financial liquidity. Dairy cooperatives are characterised by a low level of profitability of assets and capitals, which is justified by the specificity of their operations. Such dependence was also observed in the research pertaining to the European dairy cooperatives. The findings of Soboh et al. (2011) showed that cooperatives are less profitable, but they operate more efficiently and have higher financial liquidity than companies owned by investors.

There is a relationship between current financial liquidity and profitability ratios of own equity and assets in total. The highest profitability was found in cooperatives with liquidity falling within the range of 2.0-4.5. Taking into account the research carried out in this field by the Author in 2004-2006, it can be concluded that the most effective activity was demonstrated by cooperatives in which the current liquidity ratio ranged from 1.2 to 3.37 . In the surveyed years cooperatives from these groups generally achieved the highest profitability ratios and most favourable levels of farm efficiency indicators (Chmielewska, 2007). When comparing the liquidity and profitability of dairy cooperatives, it should be emphasised that this is a very important aspect of the analysis of the financial condition of these entities. The managers who manage them must reconcile the two equivalent objectives of the activity, which are the maximisation of benefits for cooperative owners and obtaining high financial results.

Cooperatives for which excess liquidity was noted, recorded shorter payment deadlines as compared to trade receivables' implementation time. In the short-term, this situation may be beneficial due to the fact that the benefits for members of the cooperative - dairy raw material suppliers who have priority in receiving cash are preserved. In economic practice, over-liquidity occurs in cooperatives that are economically strong and large in terms of own funds and total assets, where investments in modern technological lines, financed to a considerable extent from the EU funds, have been completed. In the case of cooperatives with overall liquidity within the range of 1.1-2.0, liabilities were financed using the receivables from customers. A similar situation occurred in the group of cooperatives with the lowest current liquidity ratio (0.5-1.0).

A relationship was found between the level of indebtedness of general dairy cooperatives and the current financial liquidity. As the overall liquidity ratio declined, total debt increased. Cooperatives with the lowest liquidity of 0.5-1.0 recorded the highest debt - at the level of over $60 \%$. Such a situation may be caused by the fact that managers of cooperatives with the lowest liquidity ratios have to be in debt in order to meet their supplier-members' obligations on time. Also Ananiadis, Notta and Oustapassidis (2003), when researching the relationship between the capital structure of Greek dairy cooperatives and their financial condition, concluded that the level of financial liquidity affects the level of indebtedness of these entities and differs significantly compared to commercial dairy enterprises. 
Taking into account the specific nature of the activity, it can be seen that the most advantageous financial condition was characteristic for dairy cooperatives with liquidity above and within the recommended literature standards. Such a situation may arise from the fact that having an appropriate level of financial liquidity in a cooperative may be more important than maximizing financial results. 


\section{References}

Akridge, J.T., Hertel, T.W. (1992). Cooperative and Investor-Oriented Firm Efficiency: A Multiproduct Analysis. Journal of Agricultural Cooperation, vol. 7, pp. 1-14.

Ananiadis, Y., Notta, O., Oustapassidis, K. (2003). Cooperative Competitiveness and Capital Structure in the Greek Dairy Industry. Journal of Rural Cooperation, no. 31(2), pp. 95-110.

Bednarski, L., Borowiecki, R., Duraj, L., Kurtys, E., Waśniewski, T., Wersty, B. (1996). Analiza ekonomiczna przedsiębiorstwa. Wrocław: Wydawnictwo Akademii Ekonomicznej im. Oskara Langego we Wrocławiu.

Chaddad, F.R., Cook, M.L. (2010) Understanding New cooperative models: an ownership-control rights typology. Rewiew of Agricultural Economics, vol. 26, no. 3, pp. 348-360.

Chadwick, L. (1984). Comparing financial performance: Ratio analysis and retail management. International Journal of Retail \& Distribution Management, no. 12(2), pp. 375-384.

Chmielewska, M. (2006). Wielkość majątku a kondycja finansowa spółdzielni mleczarskich. In: Współczesne problemy analizy ekonomicznej (pp. 43-50). Prace i materiały Wydziału Zarządzania Uniwersytetu Gdańskiego, no. 1. Sopot: Wydawnictwo Stowarzyszenia Księgowych w Polsce.

Chmielewska, M. (2007). Płynność bieżąca a efektywność gospodarowania spółdzielni mleczarskich. Zeszyty Naukowe Uniwersytetu Szczecinskiego, Prace Instytutu Ekonomiki i Organizacji Przedsiębiorstw, no. 50, vol. 2, pp. 111-120.

Domańska, T. (2015). Płynność finansowa a wielkość spółdzielni mleczarskich, Zeszyty Naukowe Uniwersytetu Szczecińskiego, no. 855, Finanse, Rynki Finansowe, Ubezpieczenia no. 74, issue 2, pp. 281-293.

Dworniak, J. (2010). Ekonomiczno-finansowe skutki zmian funduszu udziałowego w spółdzielniach mleczarskich. Warszawa: Wydawnictwo SGGW.

Franc-Dąbrowska, J. (2008). Jak kształtowano płynność szybką i natychmiastową w przedsiębiorstwach rolniczych? Zeszyty Naukowe SGGW w Warszawie, Ekonomika i Organizacja Gospodarki Żywnościowej no. 64, Warszawa, pp. 39-53.

Karbownik, L. (2012). Pojęcie oraz obszary kreowania bezpieczeństwa finansowego przedsiębiorstwa. Acta Universitat Lodziensis, Folia Oeoconomica, no. 267, pp. 77-93.

Ling, K.C. (2012). The Nature of the Cooperatives: A Dairy Cooperative Case Study. USDA Rural Development.

Łukasik, G. (2009). Analiza finansowa w procesie decyzyjnym współczesnego przedsiębiorstwa. Katowice: Wydawnictwo Uniwersytetu Ekonomicznego w Katowicach.

Manfredo, M., Richards, T.J. (2007). Cooperative risk management, rationale, and effectiveness: the case of dairy cooperatives. Agricultural Finance Review, vol. 67, issue 2, pp. 311-339.

Michalski, G. (2001) Pomiar poziomu płynności finansowej w przedsiębiorstwie - wybrane zagadnienia, Zarządzanie finansami firm - teoria i praktyka. Prace Naukowe Akademii Ekonomicznej im. Oskara Langego we Wrocławiu, no. 894.

Pietrzak, M. (2006). Efektywność finansowa spółdzielni mleczarskich - koncepcja oceny. Warszawa: Wydawnictwo SGGW.

Pietrzak, M. (2010). Klasyczne i dedykowane wskaźniki oceny efektywności spółdzielni mleczarskich na przykładzie uczestników IV Rankingu Forum Spółdzielczości Mleczarskiej. Roczniki Nauk Rolniczych, seria G, vol. 97, issue 4, pp. 172-182.

Sierpińska, M., Jachna, T. (2002). Ocena przedsiębiorstwa według standardów światowych. Warszawa: PWE.

Soboh, R., Oude Lansink, A., van Dijk, G. (2011). Efficiency of Cooperatives and Investor Owned Firms Revisited. Journal of Agricultural Economics, no. 63, 1, pp. 142-157. 
Soliwoda, M. (2012a). Relacje majątkowo-kapitałowe, a rentowność i płynność finansowa spółdzielni mleczarskich. Prace Naukowe Uniwersytetu Ekonomicznego we Wrocławiu, no. 261, pp. 409-423.

Soliwoda, M. (2012b). Efektywność finansowa spółdzielni mleczarskich województwa mazowieckiego. Zeszyty Naukowe Uniwersytetu Szczecińskiego, no. 112, Finanse, Rynki Finansowe, Ubezpieczenia, no. 51, issue 2, pp. 371-380.

Wasilewski, M., Chmielewska, M. (2006). Strategie zarządzania kapitałem obrotowym a sytuacja finansowa spółdzielni mleczarskich. Roczniki Nauk Rolniczych, Seria G, vol. 93, issue 1 , s. 102-111.

Wędzki, D. (2003). Strategie płynności finansowej przedsiębiorstwa. Kraków: Oficyna Ekonomiczna. 


\title{
POZIOM BIEŻĄCEJ PŁYNNOŚCI A EFEKTYWNOŚĆ FINANSOWA ORAZ SPRAWNOŚĆ GOSPODAROWANIA SPÓŁDZIELNI MLECZARSKICH
}

\begin{abstract}
Abstrakt
W opracowaniu określono rentowność majątku i funduszy własnych, sprawność gospodarowania oraz poziom zadłużenia spółdzielni mleczarskich $w$ zależności od poziomu ich bieżacej płynności finansowej. Spółdzielnie pogrupowano według wskaźnika płynności bieżacej z wykorzystaniem metody kwartyli oraz przeprowadzono test na istotność różnic między grupami. Przyjęto do weryfikacji hipoteze, iż spółdzielnie mleczarskie o płynności finansowej powyżej zalecanych standardów literaturowych wykazuja najwyższq efektywność działalności, co - z uwagi na teoretyczne aspekty tego zagadnienia - może wydawać sie kontrowersyjne. W spółdzielczej formie gospodarowania na rynku mleka istotniejsze od poziomu wyników finansowych jest utrzymywanie płynności finansowej na bezpiecznym poziomie z punktu widzenia możliwości terminowej zapłaty za dostarczone mleko swoim członkom - rolnikom - dostawcom. Wyniki badań potwierdziły, że najkorzystniejszym poziomem rentowności majatku i kapitału charakteryzowały się spółdzielnie mleczarskie o płynności finansowej powyżej zalecanych standardów. Warto zauważyć, iż według teorii $w$ zakresie płynności ogólnej spótdzielnie te byłyby zakwalifikowane jako posiadajace nadpłynność finansowa. W spółdzielczych formach przedsiębiorstw należy rozpatrywać zagadnienie płynności finansowej z uwzględnieniem specyfiki ich działalności. Utrzymywanie wysokiej zdolności do regulacji zobowiąań bieżacych warunkuje dobre funkcjonowanie spółdzielni na rynku, przede wszystkim w aspekcie zachowania ciagłości dostaw surowca mlecznego.
\end{abstract}

Słowa kluczowe: spółdzielnie mleczarskie, płynność finansowa, efektywność finansowa spółdzielni mleczarskich.

Accepted for print: 15.06.2018.

Unless stated otherwise all the materials on the website are available under the Creative Commons Attribution 4.0 International license.

Some rights reserved to the Institute of Agricultural and Food Economics - National Research Institute.

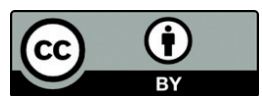

